\title{
From Residents to Neighbours: The Making of Active Citizens in Antwerp, Belgium
}

\author{
Maarten Loopmans
}

(LOOPMANS M. (2006) From residents to neighbours: the making of active citizens in Antwerp, Belgium, in Duyvendak, J., T. Knijn \& M. Kremer (eds) Professionals between People and Policy:

Transformations in care and welfare in Europe, Amsterdam: Amsterdam University Press, pp. 109-121.)

The fostering of an active civil society is a basic part of the politics of the third way. (Giddens 1998: 78)

In the 1990s, active citizenship and community involvement spread as core concepts in social policies across post-welfarist North-western Europe. Active citizenship has been promoted as an indispensable tool for the regulation of society, in policing and safety policies, provision of social services, welfare and health policies, and local economic development (Body-Gendrot 2003; Mayer 2003; Uitermark 2003; Cruikshank 1999; O’Malley \& Palmer 1996; Rose 1996), but it has been particularly prominent in politics for the regeneration of - often urban - public space (Giddens 1998; Imrie 2004). These days, involvement, consultation, and participation are pervasive notions that emerge as a new specialisation of government, having moved from the sphere of theory and social critique into professional programs and knowledge. As a consequence, new relations between citizens, professionals and policy emerge. Active citizenship turns client-citizens into co-producers and co-deliverers of services, while the tasks of professionals increasingly shift from service delivery to the co-ordination and mediation of citizen involvement in policy programs. Community involvement has been described alternatively as a new successful technique or strategy to enhance the scope and effectiveness of government, or as a means to democratise policymaking and service provision. However, little attention has been paid so far to the new dilemmas, complexities, contradictions, and resistance in the relation between government and the governed that emerge when active citizens are 'made'; indeed, the readiness of citizens to become activated is all too often taken for granted (Flint 2002; Larner \& Walters 2000).

In this chapter, the analysis of a concrete program to involve residents in the management of public space reveals the practices deployed by professionals to activate city residents and to mediate between individual needs and demands of citizens, setting collective goals. More specifically, I focus on the way these practices affect how 
'activated citizens' think about themselves and their relation to their neighbourhood, city and fellow citizens, leading to potentially disturbing contradictions that provoke mixed feelings and resistance.

The subject of analysis is Opsinjoren, a policy program in Antwerp, Belgium. Opsinjoren is a branch of the Opzoomeren family, a community involvement program developed in Rotterdam in the early 1990 s and subsequently exported as a 'best practice' to other Dutch cities and abroad (for instance, Copenhagen in Denmark and Genk and Antwerp in Belgium). Like its Rotterdam forerunner, Opsinjoren draws on the involvement of active neighbourhood residents in public space management to address new collective problems (aggregated under the common denominator 'liveability') that cannot be regulated efficiently 'from the centre'.

The chapter draws on empirical material collected through occasional conversations and participant observations (both as participant resident and while participating in on-thespot visits to resident groups - called 'jury rounds' hereafter - together with Opsinjoren professionals), in-depth, semi-structured interviewing (of politicians, professionals and active residents, individually as well as in group) and analysis of written sources (newspaper articles, promotional leaflets, and internal documents of the Opsinjoren team).

The first section introduces the characteristics of the Opsinjoren program. First I outline the way Opsinjoren presents itself: The program's goal as set by the local government, the rationale for seeking out community involvement, and the practices deployed to get citizens involved. I then discuss how 'active citizens' think and feel about their involvement and relation with the local government, their neighbourhood and their neighbours. Finally, the conclusion can be read as a warning as the techniques deployed to activate citizens not only stimulate participation but also contestation. A double tension arises from the deployment of citizens for the government of public space: First, between the visions and expectations of active citizens themselves and the goal of the program; second, between the expectations of active and 'passive' residents. Managing and attenuating this double tension is and will remain a principal challenge for the professionals running the program.

\section{Opsinjoren at Work (1)}

Opsinjoren started in Antwerp in 1997. Its name is a contraction of Opzoomeren, with the age-old nickname for Antwerp citizens, señores or sinjoren. It was funded by the then 
urban policy fund of the Flemish government, Social Impulse Fund (SIF), which had as one of its main purposes enhancing the quality of life in cities, particularly in the most deprived urban neighbourhoods. This is exactly the target of Opsinjoren, whose official purpose, as formulated on its website, is

encouraging communities to take initiatives to increase the quality of life and the 'liveability' of streets and neighbourhoods. The project aims at creating and reinforcing social networks, involving them in neighbourhood management, using the creativity and activity available, and stimulating engagement of local residents, organisations and schools by rewarding them for extraordinary initiatives or activities. (http://Opsinjoren.antwerpen.be)

The Opsinjoren program offers two types of 'reward' or support for once-only activities, and two types of support for more permanent activities. The Premie op Actie (Bonus for Action) rewards and provides financial and logistic support for residents' own initiatives, while the Stedelijke Actiedagen (Urban Action Days) are specific actions organised more top-down and city-wide, in order to give greater publicity to the program and attract new active residents. Initiatives could focus on the development and maintenance of streetbased social networks (e.g., street barbecues, Christmas drinks) or on enhancing the quality of the living environment (sweeping one's street, putting flowers on the window sill, etc.). After an internal evaluation in 2001, it was decided to put more emphasis on the latter goal. Opsinjoren was sometimes laughed off as a 'free party fund', so the organisation felt the need to produce more 'visible' results, i.e., cleaner, greener and safer streets. Hence the number of 'free parties' per street committee sponsored by Opsinjoren is now limited to three, and in public communication an emphasis is put on the coproduction of quality neighbourhood space.

It was also decided that the program should insist on a more enduring engagement of citizens; attempts were made to turn once-a-year activities into buurtcontracten (neighbourhood contracts/BCs) and to look for straatvrijwilligers (street volunteers/SVs). $\mathrm{BCs}$ are contracts between the city and at least five neighbours, whereby these citizens promise to take care of the cleanliness-greenness and/or safety of a square, playground or street on a permanent basis and in close collaboration with the city departments concerned. A SV does the same, but on his own. 
From its very start, the Antwerp population warmly welcomed Opsinjoren. In 1997, 3000 households participated in the first Lentepoets (Spring cleaning, the main Urban Action Day), a number that continued to rise to 9500 in 2005 (over $4 \%$ of the city's total number of households). The number of SVs rose from a mere 24 in 1999 to 553 in 2005 (De Antwerpenaar 2005). Among decision makers, Opsinjoren is equally popular. In 2003, when the Flemish government abolished the Social Impulse Fund and replaced it with the City Fund (Loopmans 2005), many social programs in Antwerp faced budget cuts or were discontinued, but the budget of Opsinjoren continued to rise unabated (compare Stad Antwerpen and OCMW Antwerpen 1997; 2000 with Stad Antwerpen 2003). Opsinjoren now has an annual budget of nearly EUR 1,100,000. Its goal is to support at least 750 different neighbourhood initiatives - a goal that was already surpassed in 2001 (Stad Antwerpen 2002).

\section{The Opsinjoren Rationale: Together for a Liveable City}

The popularity of Opsinjoren, both with citizens and politicians, can be explained by the fact that it seems to grapple successfully with problems of liveability, a concept introduced by the Social Impulse Fund in 1996. This Fund was an explicit reaction against the electoral rise of the extreme-right party, the Vlaams Blok (see Loopmans et al. 2003; De Decker et al. 2005). The electoral success of this party was linked by social scientists and political analysts to a range of 'minor' issues that provoked discontent among residents of deprived neighbourhoods, such as street litter, feelings of anomy, intercultural conflicts, vandalism and petty crime.

Liveability was introduced as a container concept that made it possible to talk about the same problems while naming them differently, and it has now become a central concept for urban governance in Antwerp. The ephemeral character of many of these 'minor incivilities' makes them difficult to tackle. Street litter, loitering, noise pollution, drug trafficking, streetwalking... most of these phenomena are not targeted effectively by traditional police actions. To throw a bag full of litter on the street only needs a second of invisibility. The Antwerp city council has deployed a huge number of workers to tackle the problem of littering (police, neighbourhood surveillants, square surveillants, specialised sweeping squads called White Tornadoes; the most recent attempt featured regular officials sworn in as 'litter controllers'), with fairly little result. As Allen (2003) has noted, the power to control directly from the centre simply does not reach widely enough in time and space. 
Opsinjoren intends to solve this problem of reach by involving local residents. Instead of controlling from the centre, control is split up among hundreds of 'street volunteers' and local social networks. These informal 'inspectors' remain at their post even when the formal ones go home; Opsinjoren functions 24 hours a day, 7 days a week.

In addition, active local residents are very motivated and efficient. While professionals might first consider their own safety or are hindered by rules of politeness and competence, street volunteers do not keep their mouth shut for offenders, even though this could lead to aggressive reactions, and they sometimes find creative solutions that officials are not allowed to suggest.

$\mathrm{B}$ and $\mathrm{C}$ run a compost park together with some other neighbours. The park is open to the local residents several days a week, the volunteers keep an eye on them putting their kitchen refuse in the right bin. But whenever the park is closed and nobody is there, children climb over the fence and make a mess. Both men proudly presented a creative solution to the problem: they planted spiky bushes around the fence and fertilised them with the compost. In no time, they had grown tall and now very efficiently deter children from climbing the fence. While we were talking to them and congratulating them for their invention, two neighbourhood surveillants turned up. 'You are not allowed to grow spiky plants in public space, the police code states', they say. 'You should remove them'. 'But who will keep the kids from climbing the fence?' 'When we are here, we tell them not to do it. But we cannot do more than that. When we are gone, they do what they like'. (Observation on jury round, 3 September 2004)

Apart from directly controlling fellow residents, participants also enhance the functioning of city institutions. They make visible otherwise 'invisible' neighbourhoods and streets to 'distant' public services. As day-to-day observers, they see and hear more than the remote bureaucrat or politician who has to make policy.

A great advantage of our contacts with the residents' groups is the signals we receive. Through these groups we perceive what the needs of the population are. This is very important. We constantly reorganise our sweeping plans. With these signals, we can reorient our sweeping plan more efficiently. 'Signals from the citizen' can also be used to support decisions: when there is a conflict between two 
departments, they can be a good argument. (Head of the Antwerp Sanitation Department, interview 24)

Through Opsinjoren-supported networks of residents, city authorities are more swiftly informed about new problem areas and about what and who provokes these problems. Politicians, various sections of the sanitation department and the local police eagerly make use of these 'eyes and ears' on the street.

In addition, Opsinjoren helps the local bureaucratic top control the work of fieldworkers. Opsinjoren has enabled residents to find a very approachable channel for all kinds of complaints about garbage collectors, neighbourhood surveillants or local police officers who are not doing their job properly, and some of the more established resident networks and street volunteers have even developed direct contacts with local top-level officials and politicians themselves.

I not only attend their meetings, many of them have my e-mail, and in the most problematic areas I'm in touch with residents on a day-to-day basis. I get mails from residents all the time, informing me about the local situation. (Head of the Antwerp Sanitation Department, interview 24)

\section{Luring Residents into Action}

Opsinjoren is good, because it's cash on the nail. We do something and they give us something. That's why Opsinjoren is a good service to work with. (Resident, interview 33)

Guaranteeing successful 'community governance' of public space does rely on the willingness of the population to collaborate. Hence, the main task for Opsinjoren professionals consists of motivating people and bringing them into line in order to make them deployable for increasing the liveability of the neighbourhood. Except for the material and logistic support for their activities, the core element is that when you become an Opsinjoor you attain a special position; you enter into a special relation with your city. Opsinjoren creates a distinction between active and passive residents. Two principles of distinction are applied: First, active residents are allowed to partially appropriate certain parts of public space; second, they are given exclusive access to 
networks of urban government, something that is very difficult for other residents and users of the neighbourhood to obtain.

The idea of making residents appropriate parts of public space so as to take more responsibility for it and exert social control over it was formulated by Oscar Newman (1972). This is also a leading principle in Opsinjoren. By allowing residents to plant and take care of a nearby flowerbed, Opsinjoren counts on the fact that they will also supervise it. The Opsinjoren coordinator formulates it as such:

If the City does it, residents don't feel like it is theirs. It is only because the ground is drenched by their own sweat that people will say: 'that's mine, I have put a lot of effort into that, I have been thinking about it, we have organised ourselves around it. It's a part of my environment, I have put a lot of energy into it, and you are going to respect it, I will make sure you do'. (Opsinjoren coordinator, interview 1)

Opsinjoren brings volunteers in touch with the network of government institutions that are engaged in the neighbourhood, even when it considers problems that are not directly linked to the activities of Opsinjoren. Since the problem of liveability touches upon various policy domains, Opsinjoren comes in touch with a wide range of city services (the department of open space planning, street cleaning, community building and the police collaborate on a regular basis); when necessary, Opsinjoren brings them in touch with dissatisfied residents. Opsinjoren professionals function as middlemen for 'their' residents, guaranteeing a swift and efficient solution of a variety of problems.

We cross $\mathrm{M}$ on the street, he volunteers at the garbage park. He immediately starts off complaining about litter. 'We need to hold another meeting, with the litter department, with Opsinjoren and with the police. The problems are huge. Last week, there was this Eastern European with a broken sports bag full of garbage. He threw it on the street. I told him, “don't, it's going to cost you 135 euros, I'll call the cops". After some quarrelling, I went to the police, but you know what? They didn't have time for me! And the Aldi shop on Ooievaar street, you should also have a talk with them too. They only have one dustbin, and they do not always put it outside. It's a regular dump out there'. (Observation on jury round, 29 September 2004) 
As mentioned previously, Opsinjoren groups also profit from their status as 'organised residents' to establish direct contacts with local officials, as well as with politicians and the media. Opsinjoren residents use their network to exert more power over their environment than other residents and users of the same space, from obtaining better service provision to agenda setting.

I find it useful that politicians attend the parties in their neighbourhood. The people are glad to see you there. Especially when they clean up, they see it as a form of recognition. When I was an alderman, I visited these activities, and then people would speak to me and say, 'what about this neighbourhood park'? And then I would say, 'ok, what's your vision? I'll put aside 6000 euros to renovate the benches'. (Former alderman, interview 6)

\section{Making Neighbours out of Residents}

There is something deeper at play behind the professional techniques of luring calculating residents. The people behind Opsinjoren made it very clear that part of the challenge also consisted of changing the way citizens think about themselves, their relation to their living environment, and the city's government and administration. Policymakers identified the attitudes of citizens as a key problem for the Antwerp city government. Increasingly, citizens seemed to have an individualistic, 'instrumental-fiscal' relationship to the city - a relationship that culminated in a very negative attitude towards city hall. The only contact politicians and officials had with residents were through 'professional complainers'. Residents only contacted the city government to claim more services and facilities for themselves, claims that simply could not always be met. A failure to do so resulted in complaints on their inadequate provision. The problem of clean streets is illustrative:

If everybody cleans in front of his or her house, the city is 'enormously' clean. But residents don't do this anymore. They have the attitude of 'the city should take care of it, what else do I pay taxes for?' But you can have 10,000 employees cleaning, and when residents keep throwing their cigarette butts on the street, or when kids on their way home from school throw their empty bags of crisps on the pavement, it's no use. (City official, interview 25) 
Opsinjoren offered a way to circumvent this 'individualistic' type of resident and to reach out to those who still feel a collective responsibility towards their city.

The Antwerp government collectively reached out to its citizens and said 'do something yourself, instead of complaining'... The core idea of Opsinjoren was that some people in the street would take initiatives themselves... Doing things collectively for your environment, that's the basis, actually. And of course, cleaning one's street is a good and simple model. (Former alderman, interview 6)

Instead of responding to individual demands by solipsistic residents, Opsinjoren focuses on 'responsible residents', who also feel emotionally tied to at least their immediate living environment.

We need to connect people to the neighbourhoods again. Neighbourhood life was disappearing. Social networks had gone. The Catholic network had disappeared, the socialist network as well. And if you live in a neighbourhood but you do not have any social ties with it... It's a fiction to create ties with a city, but it's possible with the neighbourhood. (Former alderman, interview 6)

Opsinjoren both thrives on and tries to re-establish feelings of connectedness and shared responsibility amongst the city's residents, and between citizens and their city (see also Whitehead 2004). For Opsinjoren to be successful, people had to start thinking and feeling differently about their relation with the city, or at least with their immediate living environment. What is at stake is convincing people that they do not merely inhabit a house, but also a street, a neighbourhood in which this house is situated. A home is more than just the actual building. Only when residents are convinced that they also inhabit the area around it, will they take responsibility for it and get involved in its management. The Opsinjoren motto is 'making neighbours out of residents' (De Antwerpenaar 2005). This challenge has been articulated clearly in the speech current alderwoman Pauwels wrote for the five-year anniversary of Opsinjoren.

The street and the neighbourhood are an extension of our house... Hence this street, this neighbourhood is something very precious, but also something vulnerable. We have to take good care of it. For the past five years, Opsinjoren has proven that 
together, we, the city, but above all the residents themselves, can make a huge difference. (Stad Antwerpen 2002, p. 4)

Opsinjoren puts a great deal of effort into diffusing this 'new' mental make-up amongst Antwerp citizens. Street volunteers are honoured annually at City Hall as 'good citizens', and regular promotional campaigns call on citizens to 'do it yourself'. Since the early days of Opsinjoren, a local weekly (De Streekkrant) offers a 'cake of the month' to a 'meritorious citizen' in consultation with the Opsinjoren team. Other local and national newspapers also regularly profile Opsinjoren participants in the most glowing terms.

\section{Neighbours vs. Residents}

At first glance, it appears that Opsinjoren participants have indeed taken on the subjectivity of the 'neighbourhood resident', and now think of themselves as inhabiting a neighbourhood, not just a house somewhere in the city. This seems to be the central precondition for taking responsibility for one's living environment. When asked why people participated in Opsinjoren to take care of their neighbourhood, they invariably answered -with a sense of despair in their voice - 'because we live here!'

Many respondents claimed with pride that this was indeed a new mentality, to feel part of and responsible for a neighbourhood or a street. Opsinjoren seems to have been an important trigger.

And then this old lady next door came up to me and said: I have lived in this house for 30 years, and it's the first time I even thought of putting a flower outside on my window sill. Nobody did it, until you moved here and started with Opsinjoren. I said: Are you serious? (Resident, interview 41)

This is a residential street. People did not bother each other. The first year I organised a street barbecue, many of the older residents met each other for the first time. They didn't even know each other's name, while they had lived here for decades! (Resident, interview 33b)

These positive accounts on the new 'neighbour mindset' can however be countered with more contradictory statements. Especially when engagement exceeded the organisation of a street party, respondents were sometimes very clear on the fact that they actually still 
did not consider it their task to keep the streets clean. They were quite nostalgic about the time that city sweepers took care of it. They just 'grabbed the brush' themselves because they felt deserted by city services.

We are moonlighters, moonlighters for the city. We do their job for nothing. If I did these kinds of things for a friend, I could be prosecuted. But I am doing it for the city, and they can get away with it. (Resident, interview 42)

Also, these 'new neighbours' were seldom satisfied with the results of their own - and the city's - engagement. As people are infused with the new mentality of being a neighbour, greater personal needs seem to suddenly appear concerning their environments. Identifying with the neighbourhood and the street they live in exposes them to feelings of despair. Litter and dirt become more visible and less bearable, and the uncivil behaviour or mere inactivity of others becomes an aggression upon their private self.

The Opsinjoren coach calls E (a 35-year-old lady) a 'tough cop' (not just because she works as a police officer, I have the impression). She has a very negative attitude towards her neighbours. According to her, they do not co-operate enough. 'It's impossible to motivate the people here'. She seems very demanding to me. She complains about a neighbour's lush lavender because it is too big; they should have trimmed it. The Opsinjoren coach tries to conciliate by claiming that the sidewalk is broad enough for that. (Observation on jury round, 3 September 2004)

'Active neighbours' are disappointed about those fellow citizens who do not put a similar effort into the upkeep of their residential environment. They vent a lot of frustration about the limited engagement of others:

In this street, residents received a basket with flowers to hang beside the door from the city. The contract stipulated that the residents water their flowers. The older lady who guides us around complains: 'I took mine away because they had torn it down'. (The Opsinjoren coach already knew about it: people had destroyed the lady's wall plaster as well. It cost some money to repair the wall and therefore she did not want to run the risk again.) 'Some people take care of it, but not all of them. 
When I say to them, you have to water the flowers, they say 'it rains, that's enough'. W (from the Department of Open Space Planning) says terracotta balls are useful, they absorb the water and then you only have to water the flowers every four days. 'Ok, but they do nothing. The first one over there, and those two there, they do nothing. I told them several times and they say yes but they do nothing. (Observation on jury round, 29 September 2004)

$\mathrm{H}$ (55, male) is waiting for us outside. The flowerbeds around the trees in front of his door and his neighbour's look very nice, further on it looks a little less agreeable. $\mathrm{H}$ tells us that he cleaned the whole street this morning, and already now $(13: 30)$, there is some litter. 'Sometimes I think, the more you clean, the more they throw on the street'. He tries, but does not succeed in keeping the whole street clean. When we ask, how many people are working on it, he answers, with a grin, 'What do you think?' There are only three, while many more people had signed up to help in the beginning. The Opsinjoren coach says it is a formidable result, with only a few people. Some of the flowerbeds are empty. She asks whether people still put their bin bags on the flowers. $\mathrm{H}$ claims it has not improved a bit. Further down the street we meet $\mathrm{P}$, a lady in her sixties. The Opsinjoren coach congratulates her: 'The street looks very nice, thanks to the residents!' P corrects her: 'That is to say, thanks to a few of the residents '. (Observation on jury round, 3 September 2004)

Besides non-participation, active neighbours are also simply confronted by fellow residents. Their partial incorporation into government networks and the right they obtain to exert a certain level of control over 'their' public space seems to be a thorn in the side to the less 'active' residents. In the stories I recorded, reactions from others vary from disbelief to utter aggression. Some people cannot imagine that someone would do this job voluntarily and are of the opinion that the SVs are paid by the city, while others attack them verbally and sometimes physically (2). A resident of a large social housing estate in the periphery puts it bluntly:

You cannot imagine what they shout at us. 'Stupid ass, you take away other people's jobs, etc.' (Resident, interview 42)

Pestering is a common complaint, especially amongst those who are very engaged. 
E complains that someone is obviously pestering her. 'They have already broken the mirror of my car three times. She says, 'if you stick your neck out in this neighbourhood, you get all the shit thrown at you. As a SV, you're a sitting duck'. (Observation on jury round, 29 September 2004)

The partial appropriation of public space and the apparently arbitrary control active residents exert over 'their place' in particular, provokes reactions from other residents and users.

M (70, female) guides us around 'her' flowerbed. On her own, she cleans the statue in the middle daily and keeps an eye on it. The problems are clearly overwhelming her. The monument has been thoroughly vandalised; litter lies scattered around the dustbins... 'Dogs are a problem, people let them crap here, and when I say something, they show me a finger'. M also complains that she is pestered because she takes care of the park. 'They put oil on my window sill and pilchards on my doorstep'. We say that is not nice of them and urge her to keep it up. She will, she says. (Observation on jury round, 29 September 2004)

Mr. B (65) complains that his neighbours across the street disagree with his gardening activities. "They asked me when I was going to remove "these weeds", (B is growing beds of wild flowers under the trees in his street). After a while, they turned to action: they poisoned his plants - even the tree in front of their house had died - so that they had a reason to tear them out... Mr. B sounds very sad. We all pity him. (Observation on jury round, 29 September 2004)

Confrontations by non-participating neighbours provoke conflicting feelings and thoughts in the minds of participants. This demoralises them and becomes a reason for others not to get involved in 'clean and green' streets, the core business of Opsinjoren. Many prefer to stick to low-profile street parties, often with a very small group, in order to avoid confrontations or because they do not agree with the tasks that are imposed on them. This is strikingly at odds with the goals of the Opsinjoren team, as one local Opsinjoren coach relates with some contempt: 
Here you only have parties, hardly any workers. Once at one of these parties, I suggested someone partake in the annual spring-cleaning, but she looked down at me and said: we do not want to have anything to do with that! Another group even asked me whether Opsinjoren could arrange for the city's sweeping squads to pass through their street after the party. There was always a lot of litter afterwards, they said'. (Opsinjoren coach, informal conversation)

Refraining from becoming too involved is a strategy chosen by some active neighbours to avoid burnout. As one respondent put it, as an active neighbour you must try to find a balance between 'engagement' and becoming a 'village idiot':

I only clean once a week. I've been thinking a lot about it, but I didn't want to go around cleaning up everybody's rubbish. I just wanted a reasonably clean street for myself. (Resident, interview 29)

\section{Conclusion: Warning}

The agility with which Opsinjoren connects the impetus to action emanating from individual needs and desires with policies to solve collective social problems is the main reason why the program is considered such a success. It expands the powers of city government into areas that were formerly unattainable, by making use of self-governing people. Residents are a crucial resource to attain clean and liveable streets. Opsinjoren activates residents by promoting and building upon a greater attachment to the neighbourhood or street of residence, and giving them a greater say and control over their living environment.

The techniques deployed to stimulate civic action also provoke confrontation. A double tension lies at the base of this paradox. First, a tension exists between private needs and collective goals: those attached to their living environment indeed 'take up the broom', but this often occurs more out of a feeling of desperation rather than sense of responsibility. Participants explicitly confront what they see as an unfair division of labour between the city and its citizens. Moreover, attachment to the living environment not only stimulates action, it often increases dissatisfaction and demands, as people's expectations about that same environment change.

Consequently, tensions also occur between 'active' and 'passive' neighbours. While the first group complains about the lack of engagement or poor engagement of the latter, 
some passive neighbours are also dissatisfied with the special status that active neighbours receive in the public space. They defy the partial appropriation of what they regard as totally public space (defined negatively as a 'no man's land') and the 'arbitrary' control active neighbours try to exert over it.

These tensions sometimes lead to overt confrontations that provoke demoralisation amongst the participants. Indeed, sometimes the active Opsinjoor not only faces fierce reactions from others using the public space, but often has difficulties reconciling collective goals with his own self-image and purposes as well. This is where Opsinjoren seems to come against its limitations. Finding a balance between the free involvement of citizens and purposive government action through them will likely be the dominant challenge for Opsinjoren professionals in the future.

Allen, J. (2003), Lost geographies of power, Oxford: Blackwell.

Body-Gendrot, S. (2003) Local governance, community organization, and crime: the case of France, in Body-Gendrot, S. and Gittell, M. (eds.), Social capital and social citizenship, Lanham: Lexington, pp. 25-51.

Cruikshank, B. (1999) The will to empower: democratic citizens and other subjects, New York: Cornell University Press.

De Antwerpenaar (2005) Opsinjoren maakt van bewoners weer buren, De Antwerpenaar, vol. 3, nr. 48, pg. 12.

De Decker, P., Kesteloot, C., De Maesschalck, F. \& J. Vranken (2005) Revitalizing the city in an anti-urban context: extreme right and the rise of urban policies in Flanders, Belgium. International Journal of Urban and Regional Research vol. 29 nr. 1, 152-171.

Loopmans M. (2003), 'Opsinjoren' in Antwerpen: een geavanceerde vorm van governance, Agora, vol. 19, nr. 5, pp. 17-20.

Loopmans, M., Uitermark, J. and F. De Maesschalck (2003), Against all odds: poor people jumping scales and the development of an urban policy in Flanders, Belgium, Belgeo, vol. 2, nr. 3, pp. 243-258.

Newman, O. (1972) Defensible space: crime prevention through urban design, New York: MacMillan, pp. 264.

SOMA vzw and OCMW Antwerpen (2000), Sociaal Impulsfonds Antwerpen: evaluatierapport programma 1997-1999. Antwerpen: Stad Antwerpen

Stad Antwerpen (2002) feestkrant 5 jaar Opsinjoren, Antwerpen: Dienst Samenlevingsopbouw, pp. 12

Stad Antwerpen (2003): de kracht van de stad: beleidsplan Stedenfonds 2003-2007.

Stad Antwerpen and OCMW Antwerpen (1997): beleidsplan Sociaal Impulsfonds 1997-1999, Antwerpen: Stad Antwerpen

Stad Antwerpen and OCMW Antwerpen (2000): beleidsplan Sociaal Impulsfonds 2000-

2002, Antwerpen: Stad Antwerpen 